\title{
Personnel Access Control System Evaluation for National Ignition Facility Operations
}

\author{
T. Altenbach, S. Brereton, G. Hermes, M. Singh
}

\section{June 1, 2001}

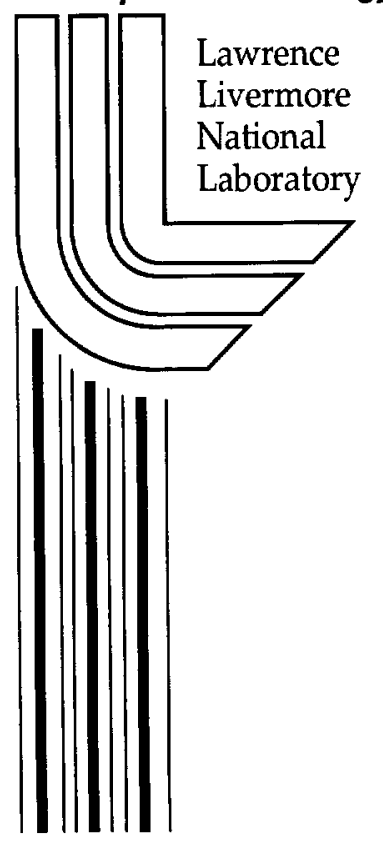




\section{DISCLAIMER}

This document was prepared as an account of work sponsored by an agency of the United States Government. Neither the United States Government nor the University of California nor any of their employees, makes any warranty, express or implied, or assumes any legal liability or responsibility for the accuracy, completeness, or usefulness of any information, apparatus, product, or process disclosed, or represents that its use would not infringe privately owned rights. Reference herein to any specific commercial product, process, or service by trade name, trademark, manufacturer, or otherwise, does not necessarily constitute or imply its endorsement, recommendation, or favoring by the United States Government or the University of California. The views and opinions of authors expressed herein do not necessarily state or reflect those of the United States Government or the University of California, and shall not be used for advertising or product endorsement purposes.

This work was performed under the auspices of the U.S. Department of Energy by the University of California, Lawrence Livermore National Laboratory under Contract No. W-7405-Eng-48.

This report has been reproduced directly from the best available copy.

Available electronically at http://www.doe.gov/bridge

Available for a processing fee to U.S. Department of Energy

and its contractors in paper from

U.S. Department of Energy

Office of Scientific and Technical Information

P.O. Box 62

Oak Ridge, TN 37831-0062

Telephone: (865) 576-8401

Facsimile: (865) 576-5728

E-mail: reports@adonis.osti.gov

Available for the sale to the public from

U.S. Department of Commerce

National Technical Information Service

5285 Port Royal Road

Springfield, VA 22161

Telephone: (800) 553-6847

Facsimile: (703) 605-6900

E-mail: orders@ntis.fedworld.gov

Online ordering: http://www.ntis.gov/ordering.htm

OR

Lawrence Livermore National Laboratory

Technical Information Department's Digital Library

http://www.llnl.gov/tid/Library.html 


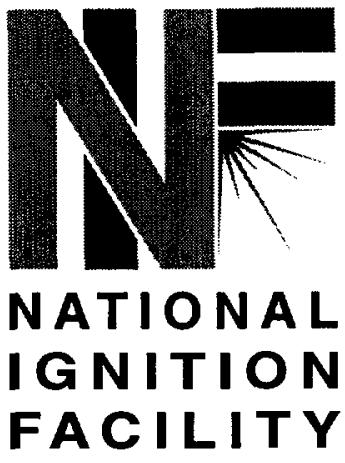

\section{Personnel ACCESS Control System Evaluation FOR NATIONAL IGNITION FACILITY OPERATIONS}

Tom Altenbach

Sandra Brereton

Glenn Hermes

Mike Singh

June 1, 2001 


\section{TABLE OF CONTENTS}

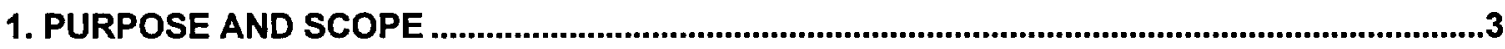

2. APPROACH

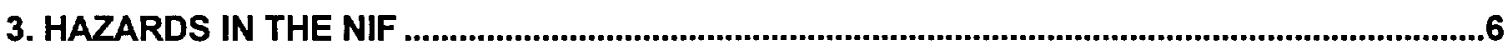

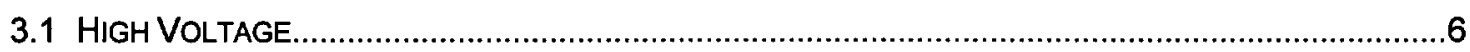

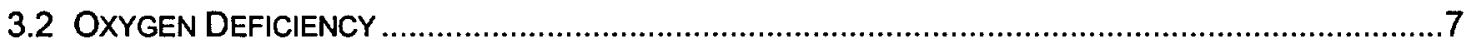

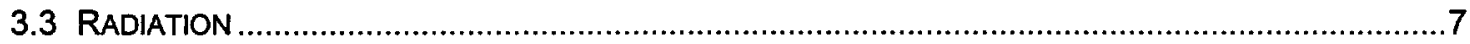

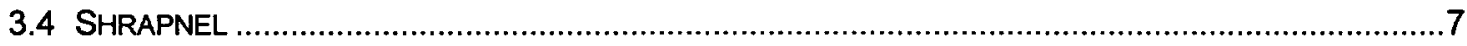

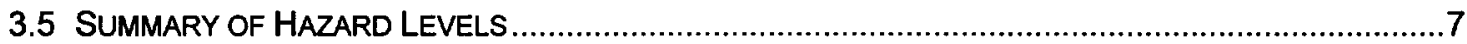

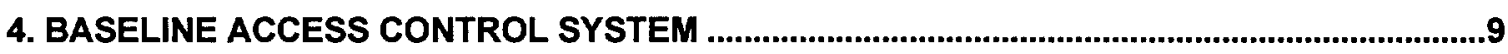

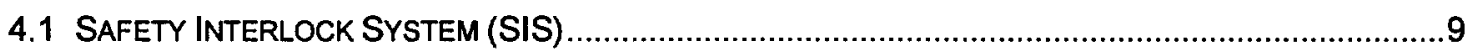

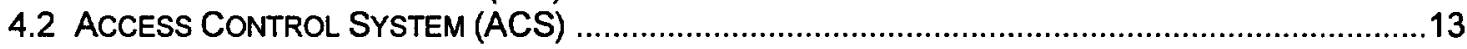

5. ACCESS CONTROL SYSTEM PERFORMANCE ANALYSIS ................................................15

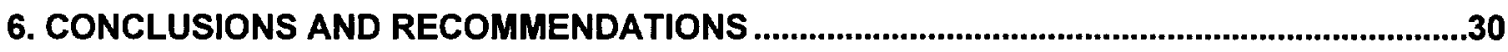

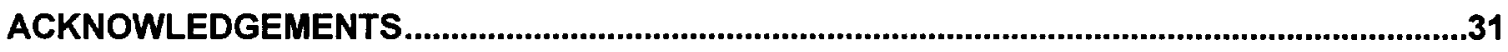

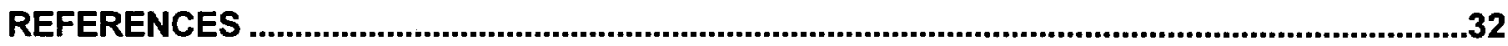

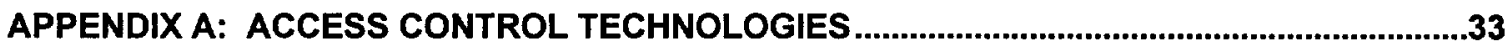

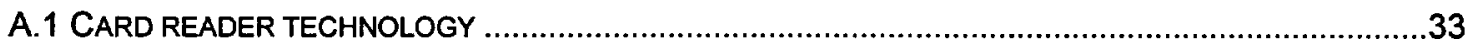

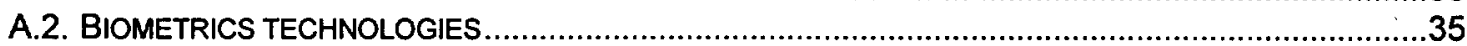

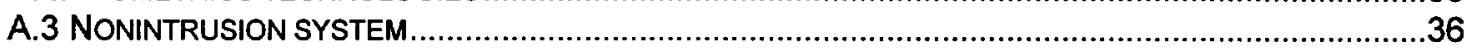

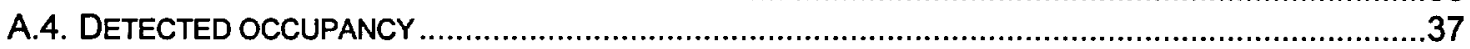

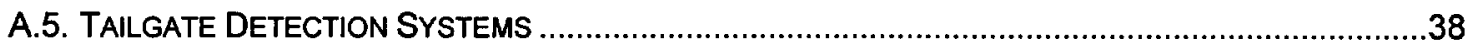

APPENDIX B: SURVEY OF ACCESS CONTROL SYSTEMS AT OTHER FACILITIES ................39 


\section{PURPOSE AND SCOPE}

The purpose of this document is to analyze the baseline Access Control System for the National Ignition Facility (NIF), and to assess its effectiveness at controlling access to hazardous locations during full NIF operations. It reviews the various hazards present during a NIF shot sequence, and evaluates the effectiveness of the applicable set of controls at preventing access while the hazards are present. It considers only those hazards that could potentially be lethal. In addition, various types of technologies that might be applicable at NIF are reviewed, as are systems currently in use at other facilities requiring access control for safety reasons. Recommendations on how this system might be modified to reduce risk are made.

Three areas within NIF potentially present lethal hazards.

- The Target Bay. The target bay houses the target chamber and all systems necessary to support experiments, target placement, target diagnostics, and support systems. The location of the target bay within the NIF is shown in Figure 1. High levels of radiation exist in the target bay during high yield shots.

- The Laser Bays. The laser bays house the main elements of the laser system that generates and delivers high-power laser light pulses to the target chamber. The location of the two laser bays within the facility are shown in Figure 1. The Laser system consists of 192 laser beams, totaling $1.8 \mathrm{MJ}$ of energy. In the laser bays, a high voltage hazard potentially exists during shots. Also, there is a laser light hazard, but this is not lethal and is not explicitly considered in this study.

- The Capacitor Bays. The NIF power conditioning system consists of a large collection of capacitors, inductors, and resistors, housed in modules with associated switches, controls, distribution system, etc. The modules are located in four capacitor bays, identified in Figure 1. The power conditioning system presents a high voltage hazard. In addition, capacitors and power conditioning systems of the type required for NIF have been known to fail catastrophically and generate shrapnel, during charging or while the capacitors are in a charged state.

The NIF is complex and presents several potential risks for workers. In order to assure personnel safety, to control when personnel are allowed in certain areas of the facility, and to assure that only qualified personnel enter each part of the facility, an access control system is required. The Access Control System tracks personnel movement into and out of the facility. The Access Control System operates in conjunction with the Safety Interlock System to provide controlled access into the facility and to track occupants as they go between access control 
zones within the facility. The Safety Interlock System functions by providing permissive signals for the operation of LTAB equipment. Permissive signals are determined by monitoring the status of various safety-related elements, which function together to reduce the risk to personnel. These elements include the Access Control System, crash and status panels, alarms, warning signs, and monitors. General features of a proposed Access Control System for NIF are described in Section 4. The analysis of the system is provided in Section 5. Refinements and recommendations for the system are summarized in Section 6.

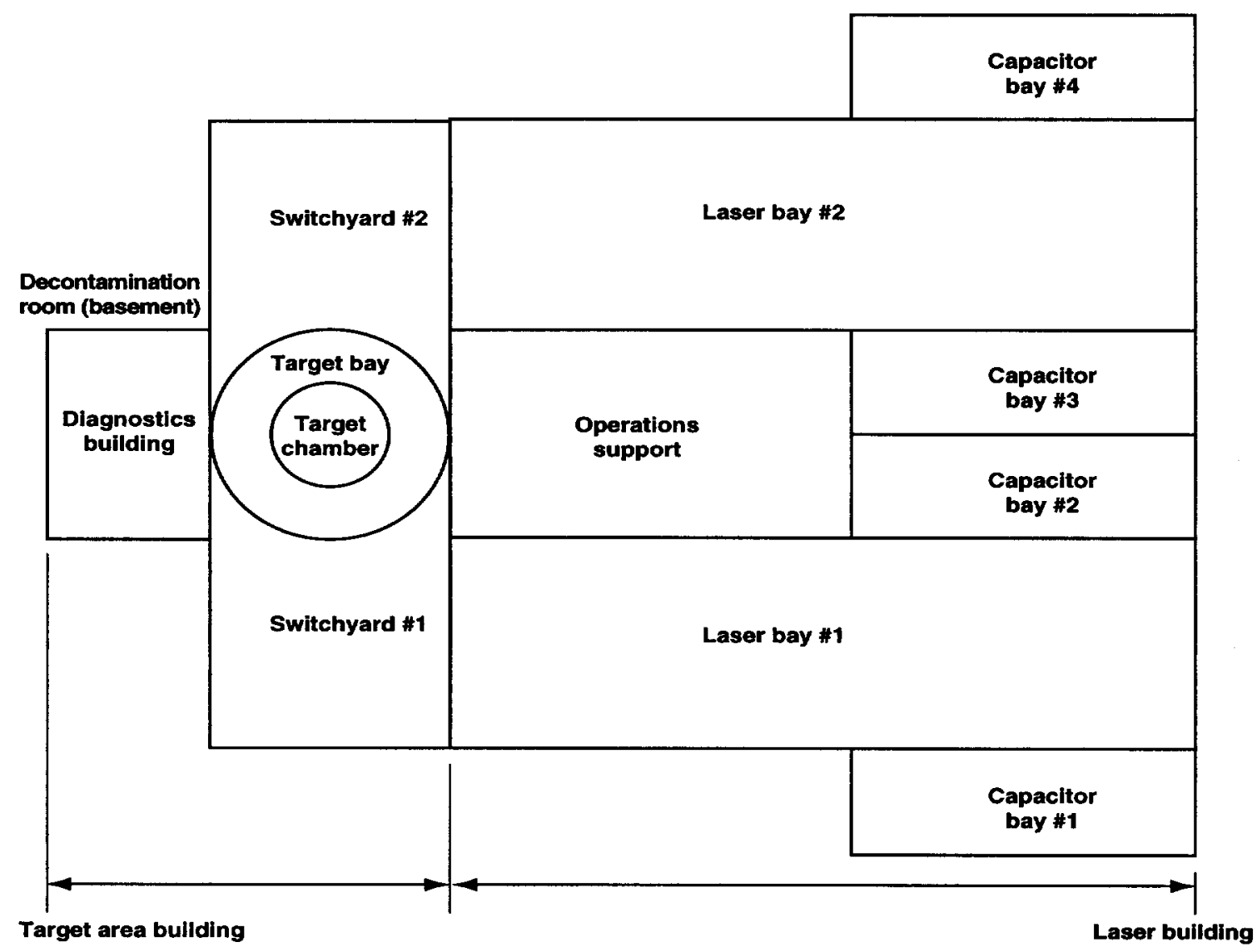

40-00-0496-0905pb02

Figure 1. LTAB plan

\section{APPROACH}

To assess the access control system for NIF, the approach used was to first examine the hazards throughout the facility. These are described and analyzed in detail in the NIF PSAR (LLNL, 1996), and draft FSAR (LLNL, 1999). The 
hazards were reviewed to determine whether or not an access control system would be an effective way to reduce the risk of exposure to the hazard. In this analysis, only potentially lethal hazards were considered. These are summarized in the next section.

The various elements of the Access Control System were considered through a combined Event Tree-Fault Tree analysis. An Event Tree graphically shows the possible outcomes of an accident that results from an initiating event. The Event Tree analysis considers the responses of safety systems and operators to the initiating event when determining the accident's potential outcomes. At each branch, the event tree sequence proceeds according to the state of the corresponding top event. If the top event is modeled as successful, the up branch is followed and the conditional probability for this normal situation is approximately 1 . If the top event is modeled as a failure or off-normal condition, the bottom branch of the sequence is followed and the conditional probability is that number shown on the tree either directly below the top event or on the branch itself. The results of the Event Tree Analysis are accident sequences, that is, sets of failures or errors that lead to an accident. These results describe the possible accident outcomes in terms of the sequence of events (successes or failures of safety functions ) that follow an initiating event. After these individual accident sequences are identified, the specific combinations of failures that can lead to the accidents can be determined using Fault Tree analysis.

Fault Tree Analysis is a deductive technique that focuses on one particular accident or main system failure, and provides a method for determining causes of that event. The purpose of a Fault Tree Analysis is to identify combinations of equipment failures and human errors that can result in an accident. The Fault Tree is a graphical model that displays the various combinations of equipment failures and human errors that can result in the main system failure of interest (called the "Top Event"). The strength of the Fault Tree Analysis as a qualitative tool is its ability to identify the combinations of basic equipment failures and human errors that can lead to an accident. Attention can then be given to preventive or mitigative measures on significant basic causes to reduce the likelihood of an accident.

The analysis documented in this report considers the potential for failure of the access control system in such a way that an individual could be exposed to a lethal hazard. In some instances (e.g., high yield shot in target bay), the lethal hazard is inherent to the operation. In other cases, an additional failure must occur in order for the worker to be exposed to the hazard (e.g., high voltage electrical fault in the laser bay during a shot). The Event Tree-Fault Tree analysis and results are presented in Section 5 . 


\section{HAZARDS IN THE NIF}

Personnel in the various areas of NIF can be exposed to several different hazards including:

- laser light,

- high voltage,

- oxygen deficiency,

- cryogenic materials,

- hazardous chemicals,

- mechanical/moving equipment/lifting,

- falls/falling objects,

- radiation,

- vacuum,

- shrapnel.

In order to evaluate the access control system, only the capacitor bays, laser bays, and the target bay will be studied, because lethal hazards to workers can exist in these areas. Of the hazards listed above, only high voltage, oxygen deficiency, radiation, and shrapnel hazards are considered. The others could result in personnel injury, but because they would not be lethal, or because the risk would not be significantly impacted by the use of access control, they are not considered in this study. Exposure to some hazards, such as laser light, can be prevented by the access control system. Any improvements in the access control system would also reduce the risk of a laser exposure injury. However, this is not explicitly studied here.

\subsection{High Voltage}

Electrical hazards are associated with high-voltage and other electrical equipment (capacitor bank, high voltages for target chamber diagnostics) and their associated wiring and connecting points. The LTAB is expected to place a maximum demand load of 13 MVA on the supply grid. The power conditioning system stores $370 \mathrm{MJ}$ of energy. If a fault occurs during the transmission of power from the capacitor bays to the flashlamps in the laser bays, a high voltage hazard may exist in the laser bays. During a worst case ground fault, the capacitor bay cable enclosure system is designed to keep any touch potentials below a $500 \mathrm{~V}$ and $3 \mathrm{~J}$ level. Thus, the electrical hazard in the capacitor bays is minimal if the design functions as intended. However, if the design fails (e.g., as a result of a maintenance error), a high voltage hazard could exist in the Capacitor Bays. Some diagnostics in the target bay employ high voltages. Failure involving those components could expose workers to high voltage. However, these exposures could not be prevented by the Access Control System. 


\subsection{Oxygen Deficiency}

Several NIF systems routinely contain material that could potentially create an oxygen deficient atmosphere (e.g., argon in beam tubes, nitrogen coolant in target chamber cryopumps). These materials reside in the system continuously, and require a failure to create an oxygen deficient atmosphere in the worker environment. In addition, systems utilizing synthetic air (e.g., amplifier cooling) could also contain a non-life-supporting atmosphere if the control system failed to mix the nitrogen and oxygen correctly. An additional failure could result in the potential for an oxygen deficient atmosphere to be created. If the oxygen monitoring and/or purge system failed, an oxygen deficient environment could be created in the worker environment. This could incapacitate a worker and prevent that individual from exiting an area before a shot occurs.

\subsection{Radiation}

There are several radiation exposure hazards at the NIF. Personnel will be exposed to prompt radiation during NIF yield shots. In the target bay, workers could be exposed to lethal doses of neutron and prompt gamma radiation if accidentally present in the target bay during a high-yield shot (>1 MJ). The access control system is critical to preventing personnel from being present in the target bay during a high yield shot.

\subsection{Shrapnel}

Capacitors and power conditioning systems of the type required for NIF have been known to fail catastrophically during charging or while the capacitors are in a charged state. Such failures can generate shrapnel, which can have velocities on the order of $1000 \mathrm{ft} / \mathrm{s}$, and initial energies of several kJs. Although the capacitor modules have been designed to contain the shrapnel, it is still prudent to keep personnel away from the area when the capacitors are in a charged state.

\subsection{Summary of Hazard Levels}

The hazard level within NIF varies as a function of location, and as a function of the point during the shot sequence. It also depends on the type of shots being conducted (e.g., non-yield, low-yield, or high-yield shots). The highest hazard level is associated with a high yield shot. The maximum hazard levels present during a shot sequence at the three primary locations of interest in the LTAB, are summarized in Figure 2. A shot sequence includes the pre-shot activities of alignment and charging capacitors, firing the laser, and the post-shot period when systems are allowed to cooldown so that alignment can begin for the next shot. Typically, this occurs over an 8-hour period. 


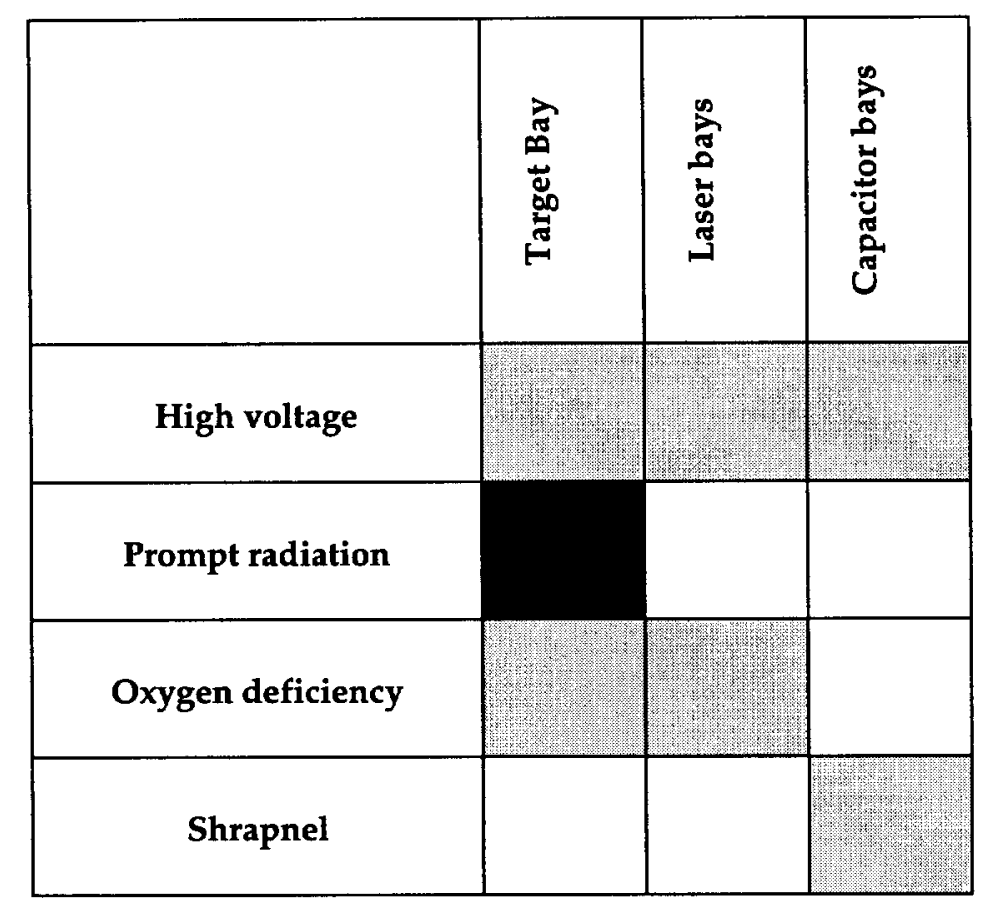

Potentially immediately lethal 5 Possibly lethal, need failure

Figure 2: Maximum Hazard Levels in Various NIF Locations during a shot sequence. 


\section{BASELINE ACCESS CONTROL SYSTEM}

NIF will have an Integrated Safety System (ISS) in place to ensure personnel safety. This ISS consists of the following personnel safety-related elements:

- The Safety Interlock System (SIS), the highest-level safety system in the LTAB, provides personnel safety interlocks and annunciation of hazard levels throughout the facility.

- The Access Control System, functions in conjunction with the SIS and an online database describing personnel qualifications to control individual access into the facility.

The main functions of the Access Control System are to track personnel entry and egress and to verify the personnel qualifications for those entering a risk area. The information is available to an operator, who manually provides it to the SIS.

The Access Control System works together with the Safety Interlock System. The SIS is described in the next section, to provide an understanding of the context within which the ACS must fit. The baseline ACS is described in Section 4.2.

\subsection{Safety Interlock System (SIS)}

The purpose of the LTAB SIS is twofold. The primary function is to work in conjunction with engineered barriers, access control, administratively controlled procedures, and operator training to protect personnel from exposure to various hazards. A secondary function is to protect high-value equipment in the event of an improper configuration or failure in a monitored component.

The SIS performs its functions by providing permissive signals for the operation of LTAB equipment such as process power supplies and alignment lasers. Permissive signals are determined by monitoring the status of safety-related elements in each bay of the facility including shutters, doors, crash buttons, and oxygen levels. The SIS does not directly control process devices, but instead provides a permissive contact in series with the device's command line from the process control system, which allows operation of the device when conditions permit.

If the interlock chain for a device is not satisfied, the permissive signal will not be enabled, and operation of the device will not be permitted. The device will assume (or stay in) its fail-safe state or position. On the other hand, if the interlock chain for a device is satisfied, the permissive signal will be granted, and normal operation of the device will be allowed. The actual operational state of the device is determined by the local process control system within the safety constraints imposed by the SIS. 


\section{SIS Design Description}

The SIS is a distributed system based on Programmable Logic Controllers (PLC). It is designed to support segmented operations throughout the facility. The NIF is divided into four zones with a different PLC being responsible for each, and the facility or "master" PLC being responsible for the coordination of operations between the others. The PLCs reside in a common chassis located in the computer room and communicate with their remote $\mathrm{I} / \mathrm{O}$ over a dedicated deterministic network. Communications between different areas of the facility are isolated via fiber optic links to minimize interference from electrical noise. Interactions between areas and facility level functions are handled by the master PLC. The master PLC periodically reads I/O status for the other area PLCs and performs an independent verification of their function. The system assumes a safe state in the event that the PLCs do not agree. The zones each PLC covers are shown in Figure 3.

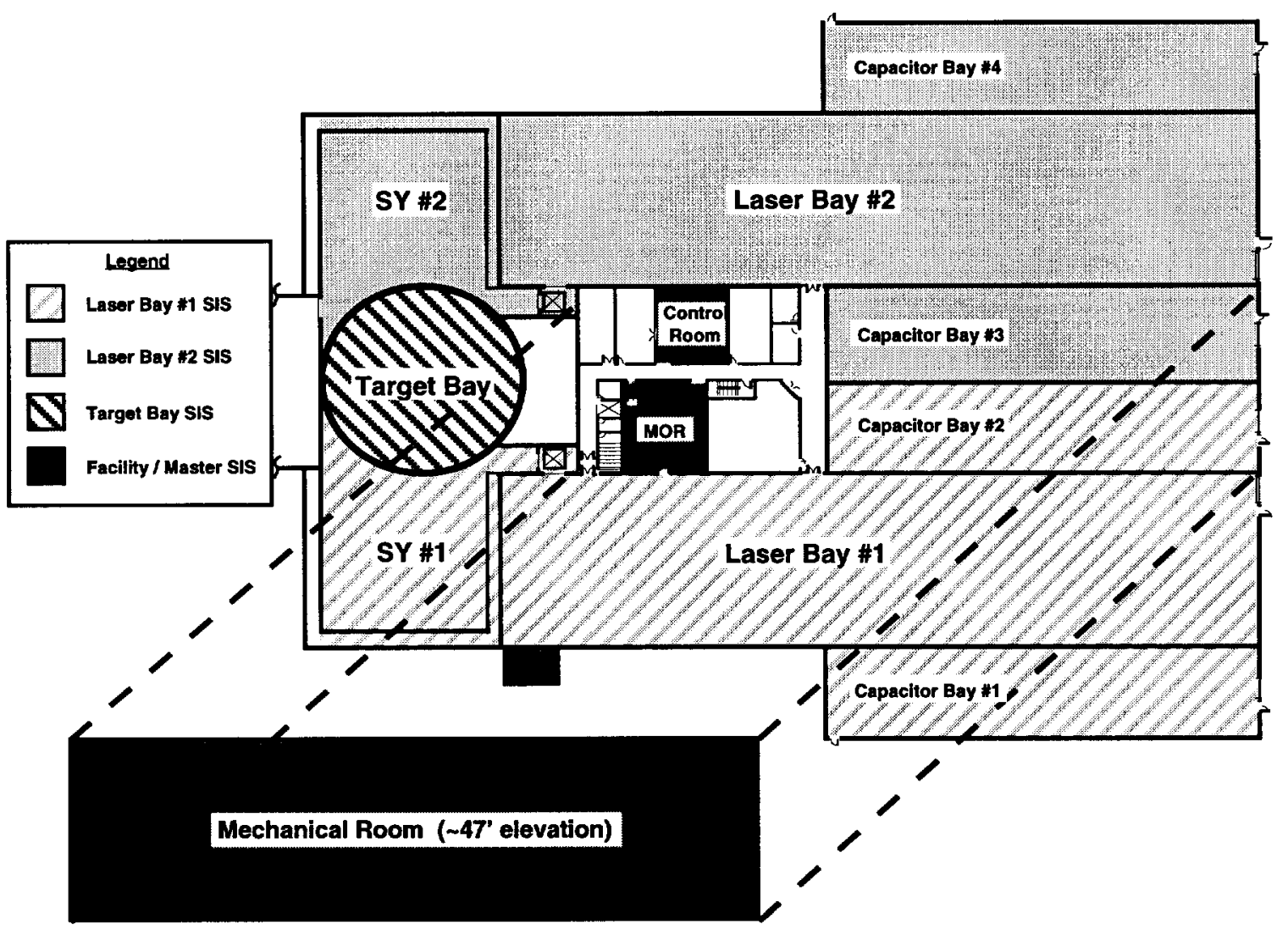

Figure 3. SIS PLC zones.

The SIS provides personnel safety interlocks throughout the facility for systems that can generate or propagate a hazard beyond their immediate controlled areas. It continuously displays the hazard levels in the facility and annunciates 
hazard-level changes. The SIS monitors the position of doors, hatches, and shutters. It also monitors crash buttons, radiation levels, oxygen levels, and provides visual status displays in the facility. Permissive signals are provided to power conditioning, safety shutters, inert gas supply valves, and other components as necessary to protect personnel and warn them of hazards in the area. It provides digitized voice annunciation of hazard-level changes in the facility.

The SIS is capable of functioning stand alone and can perform all of its safetyrelated functions without the involvement of higher-level control systems or components. The SIS can be monitored autonomously from local control consoles located throughout the facility or from the Supervisory Control System. It is designed as a fail-safe system. On a detected critical failure within the system, it shuts down its outputs forcing interlocked devices to their safe state, halting hazard-generating operations. Each SIS output module contains a watch dog timer that shuts down the module's outputs in the event that the module loses communication with the PLC. All devices interfaced to the SIS are configured such that they default to their safe state when de-energized.

The SIS accomplishes its purpose by interfacing with the following types of equipment:

- Crash \& Status panels: These panels are located throughout the facility. They contain a facility crash button, which when actuated brings the facility to a safe state by removing permissives from hazard-generating devices or operations driving them to their pre-determined fail-safe state. The panels also contain a minimum of three status indicator lights that are red, yellow, and green. These lights are always arranged in the same order and indicate relative hazard status in the facility. Green indicates that that no hazards requiring Personnel Protective Equipment (PPE) are in progress. Yellow indicates that hazards requiring PPE or special procedures may be present. Red indicates a high-danger exclusion condition. The displays may contain an alphanumeric display unit. This unit displays textual information detailing the hazard level status of the facility. These panels are equipped with a key switch for use as a sweep station that aids in the systematic evacuation of the facility prior to a shot. Warnings, such as those provided by status panels, are included in the Fault Tree Analysis presented in the next section.

- Entry Status panels: These panels are located on the entrance side of access controlled entry doors. They are similar to the crash and status panels, except they have do not have a crash button or sweep key. They contain a minimum of three status indicator lights whose function is identical to that of the crash \& status panel. They contain an alphanumeric display that displays necessary instructions for entry into the controlled area and required PPE. In addition, these panels are equipped with a badge reader interfaced to the ACS, which identifies personnel who are entering the building. The panels 
contain a three-button keypad on which the entrant presses a button acknowledging the hazard level within the facility, as the final step prior to entry. There are several specialized status panels in the system that function in a similar manner. These include the viewing gallery status, target chamber entry status, roving diagnostic enclosure status, elevator status, and capacitor bay status panels.

- Large format status displays: These are large-format tricolor dot matrix type displays located at either end of the main operations hallways in each laser bay. They are visible from approximately 250 feet and display the current hazard level status in the laser bays. Warnings, such as those provided by status displays, are included in the Fault Tree Analysis presented in the next section.

- Audible alarms: Several types of alarms are interfaced to the SIS. These range from chimes that annunciate the opening of a laser shutter to waveringtone klaxons sounding at approximately $110 \mathrm{~dB}$ during the final time before a shot. The klaxons are also used as an evacuation alarm in the event of a lowoxygen condition. Warnings, such as those provided by audible alarms, are included in the Fault Tree Analysis presented in the next section.

- Automatic digitized voice annunciation: This allows the SIS to play digitized voice warning or status messages within areas of the building via the facility public address system. These messages are used to advise of hazard level changes, announce evacuations due to pending shots, and advise of oxygen deficient areas, etc. Warnings, such as those provided by automatic digitized voice annunciations, are included in the Fault Tree Analysis presented in the next section.

- Doors: The SIS interfaces with two types of doors-emergency exit doors and access controlled doors. Emergency exit doors shut down hazardous equipment in the affected areas when opened. Controlled doors serve as the entry portals into the facility and as access points between access control zones. All SIS-monitored doors are equipped with position-indicating switches. Controlled doors are equipped with entry status panels and motion detectors on the hazard side of the door. The motion detectors trigger an automatic 15-second door bypass allowing personnel to exit the controlled area without tripping the door interlock. Controlled doors are also equipped with a 15-second bypass triggered via the entry status panel allowing personnel to enter the facility. The opening of a controlled door outside of this 15-second window results in the shutdown of any hazard-generating equipment. Entry doors are equipped with electric locks that are controlled by the SIS to prevent entry until an operator completes the entry procedure. The SIS does not inhibit personnel from exiting the facility under any circumstances. Personnel may always crash out of the facility. Operation of 
these doors is included in the Fault Tree Analysis presented in the next section.

- Radiation monitors: The SIS is capable of supporting radiation monitors at each Target Bay door, in the control room, and on the elevated release point. In the event of a high radiation reading, the SIS annunciates an alarm in the affected area and to the operators in the control room. Tritium monitoring capabilities will be installed on the elevated release point prior to any tritium use. All monitors will be installed and activated prior to high-yield target shots being operated.

- Oxygen deficiency sensors: Oxygen detectors are located throughout the facility in areas where oxygen deficiency could be a potential problem. These detectors have two independent setpoints for low-oxygen alarms. They generate and sound alarms (audibly and visually) local to the detector, and are monitored by the SIS that reports alarms to the facility and takes other actions if necessary. Oxygen monitors will be installed prior to the inclusion of oxygen displacing gases in the system components; therefore not all of the detectors will be installed until sometime during the second phase of the project. Failure of the oxygen monitors/purge system is included in the Fault Tree Analysis presented in the next section.

\subsection{Access Control System (ACS)}

The ACS operates in conjunction with the SIS to provide administratively controlled access into the facility and to track the occupants of the facility between access control zones in the facility. In the current baseline system, entry and egress through monitored doors are accomplished by sensing special badges carried by all facility occupants. Movement into and out of the facility is recorded in a transaction log that is available for use by operators and higherlevel computer systems. The specific Access Control System recommendations resulting from the analysis in this report pertain to the baseline system, or any alternate system with the same capabilities, i.e., monitoring entry and egress from the facility, and between areas within the facility.

The baseline ACS is based on a commercially available security and access control system. It functions in conjunction with the SIS to control access into the facility. It adds a layer of diversity to the SIS in that both systems are required to energize the electric door lock gaining access into the facility through one of the controlled doors as shown in Figure 4.

The baseline ACS uses an administratively controlled database that defines the individuals who have access to the facility and the areas to which they have access. It aids in the sweep and evacuation of the facility prior to a system shot in that it provides a list of the currently known occupants of the facility. The system tracks the entrance of personnel to access control zones of the facility by sensing special badges carried by 
personnel. Each person entering a controlled door must first have his badge scanned by a reader located outside the door. Multiple accesses through a single badge reading are not allowed by administrative control. The system also tracks the exit of personnel from access control zones when the person leaving has his badge scanned by another reader located inside the door. The access control zones in the facility include:

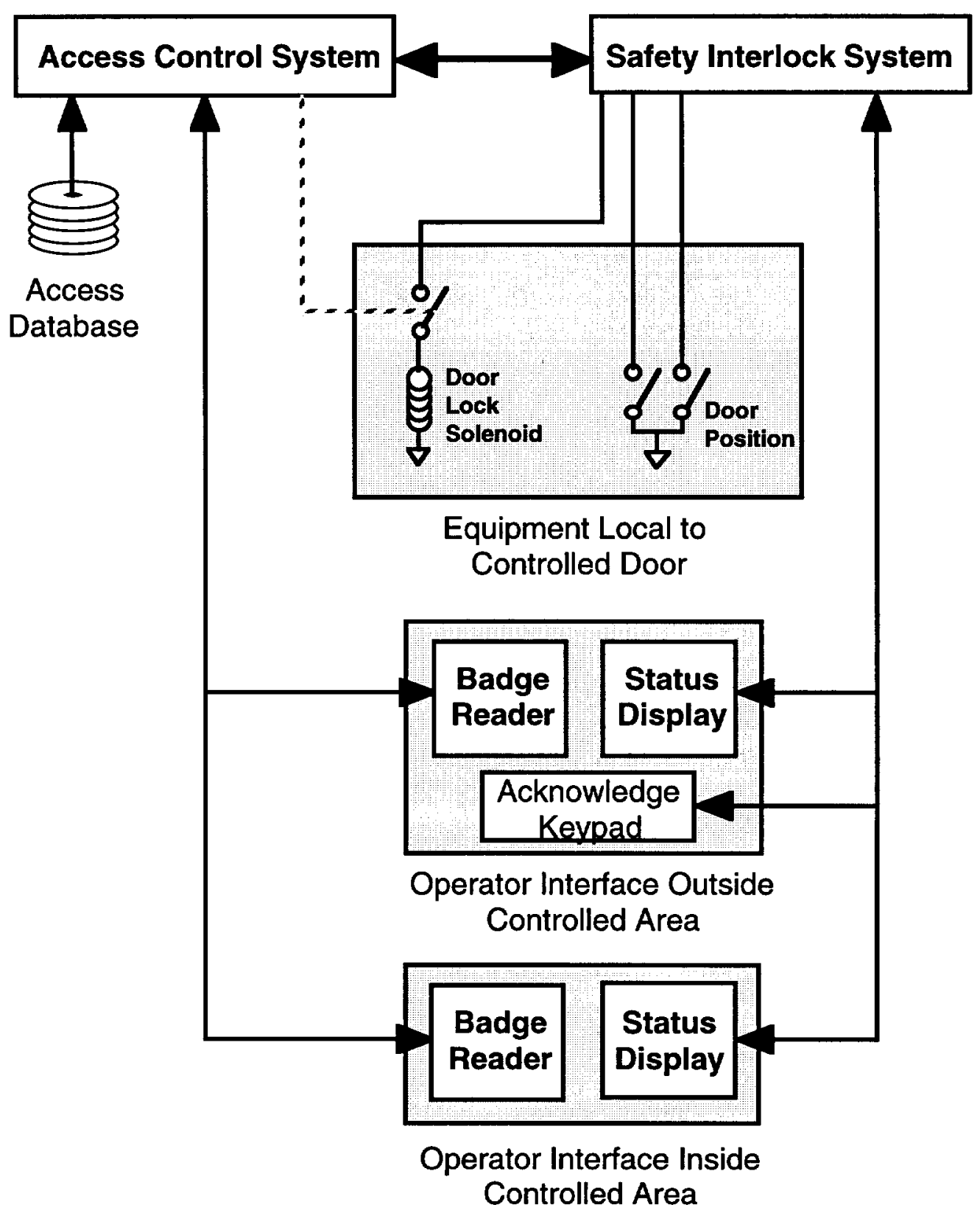

Figure 4. Typical access controlled door configuration. 
- Laser Bay 1

- Switchyard 1

- Laser Bay 2

- Switchyard 2

- Target bay

- Control room

- PAMMA

- MOR.

The system logs the occupant's name, location, and time of entry and exit to each of the access control zones. It reports by name the occupants in each zone. It has the ability to "lock down" each zone of the facility, in effect denying entry during shot sequences or other high-hazard times".

The next section provides an analysis of the Access Control System, together with various elements of the Integrated Safety System. From this, Access Control System performance recommendations will be made.

\section{ACCESS CONTROL SYSTEM PERFORMANCE ANALYSIS}

Event trees with supporting fault trees were used to model the scenarios that could result in a fatality during a NIF shot sequence. The scenarios were based on an individual being in a hazardous NIF location, then being exposed to a fatal hazard during a shot sequence. A preliminary quantification was done, to estimate the frequency of a fatality for the various scenarios. An analysis of the scenario frequencies allows us to make specific recommendations to improve performance of the Access Control System and to evaluate the effectiveness of other controls like area sweeps, for example.

There are three areas in NIF where personnel access is controlled due to the potential for a fatality during a shot sequence. These areas include the Target Bay, Laser Bays, and Capacitor Bays. An event tree was constructed for each area, to model the scenarios by which someone could access the area and be exposed to a fatal hazard during a shot sequence (see Figures 5, 6, and 7). The structure of the event trees is the same for each area, however the quantification is different.

\footnotetext{
${ }^{1}$ Emergency Services can gain access with a key. This would withdraw permissives and hazard-generating equipment would be forced to a fail-safe state.
} 


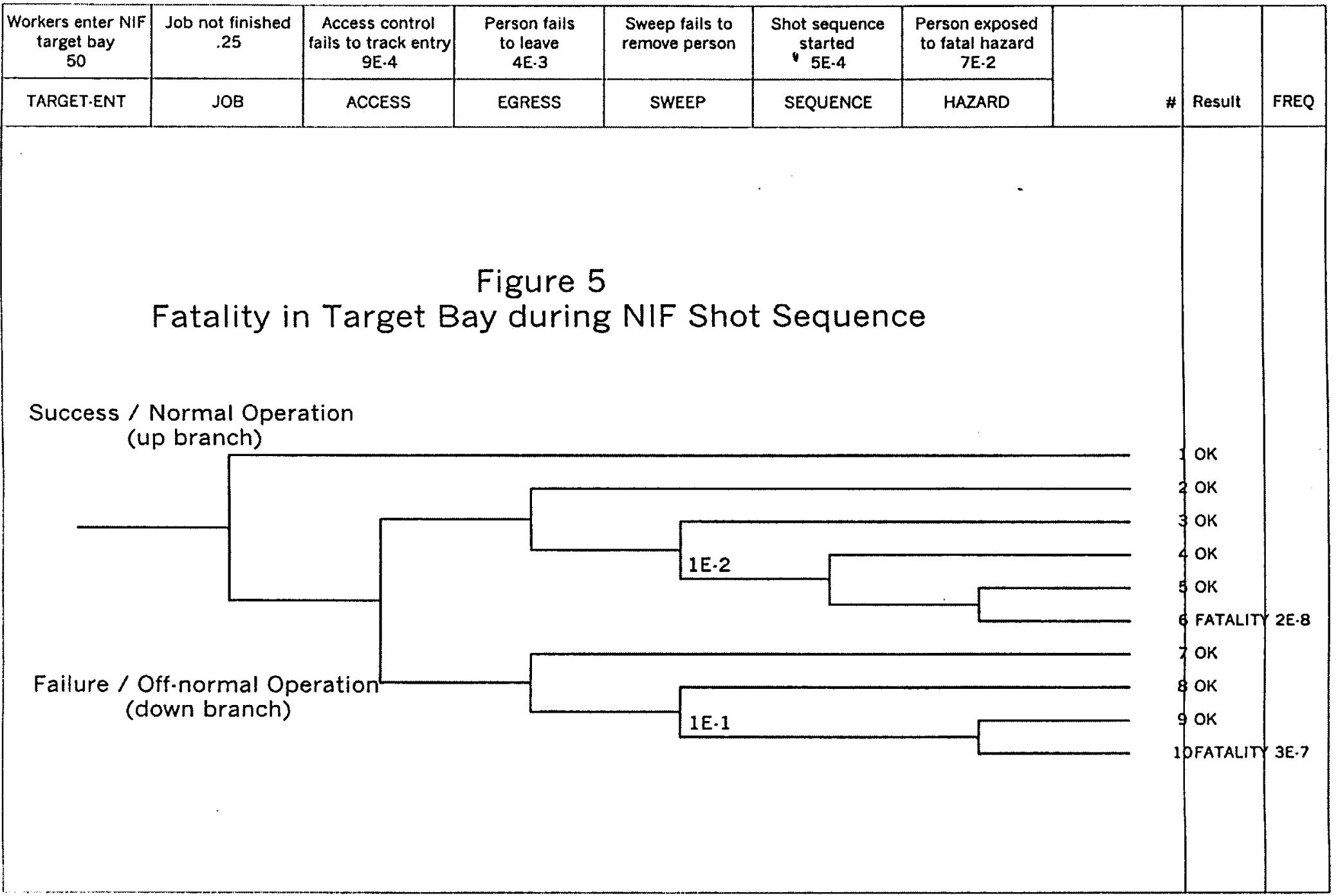




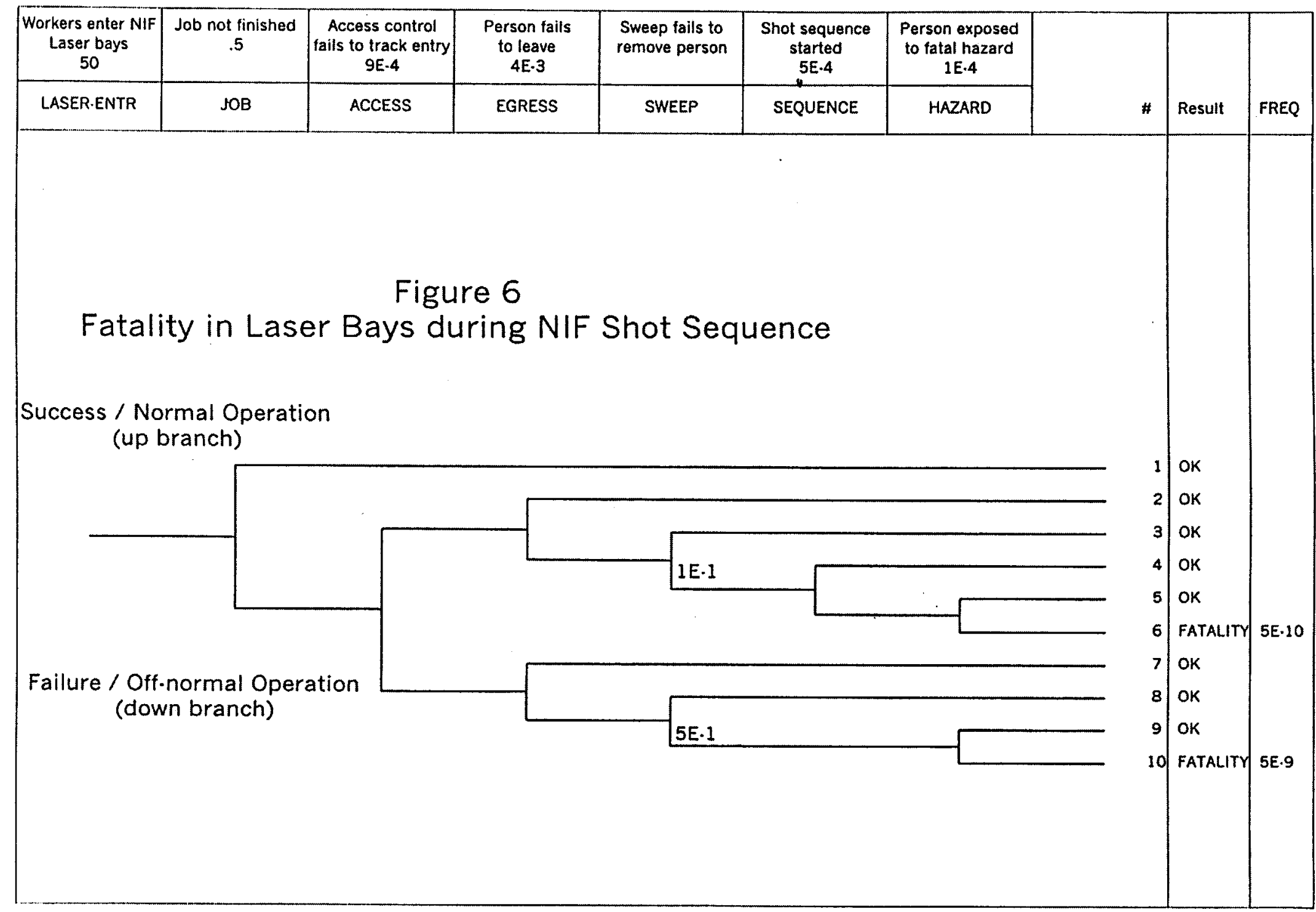




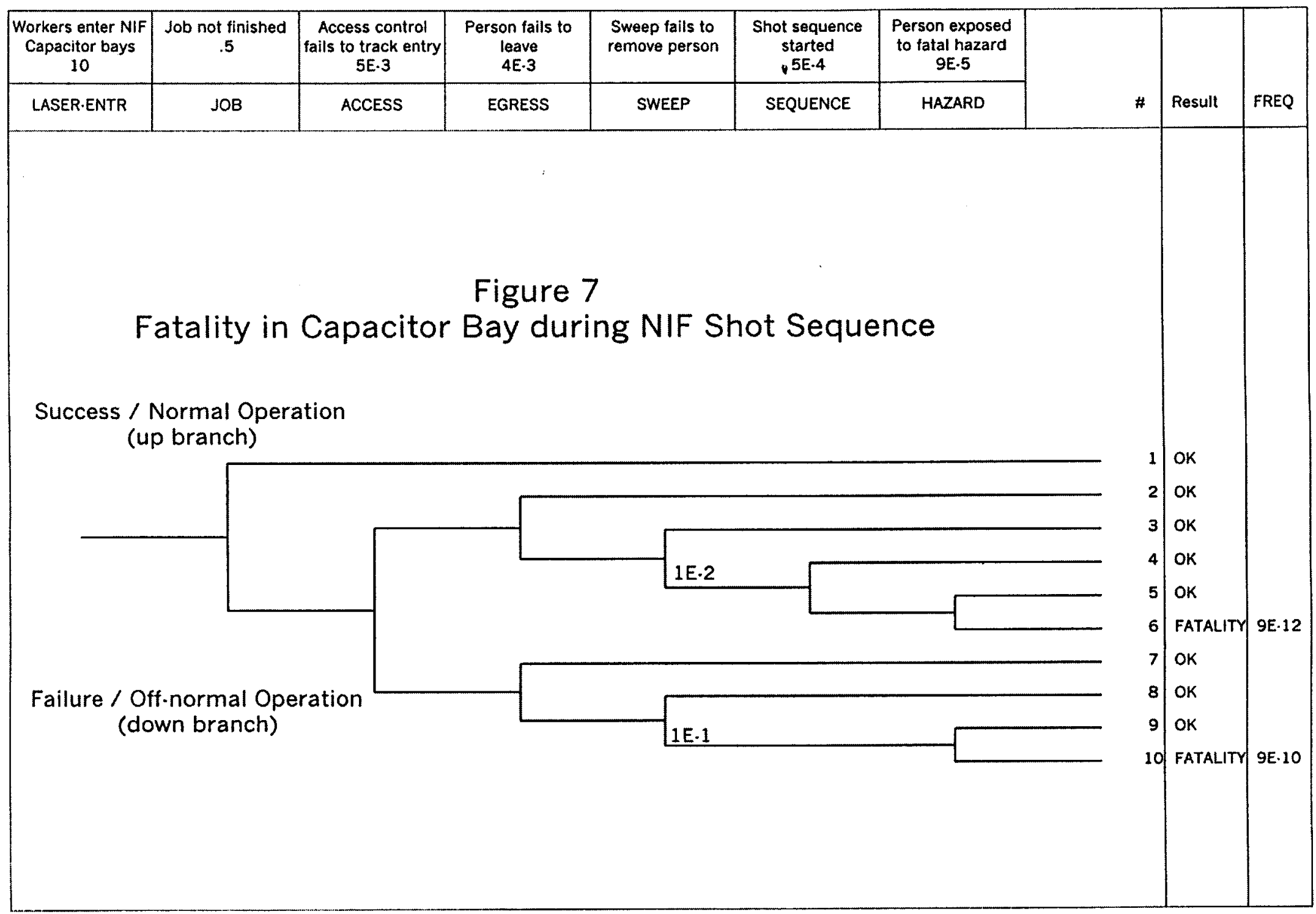


The initiating event for each event tree is workers entering the particular area. The frequency of access for each area can be different, and the values used are given in Table 1. The first branch in the event tree occurs at the top event "Job not finished". It is assumed that $50 \%$ of the workers entering the Laser and Capacitor Bays do not finish their jobs before the shot sequence initiates warnings to leave. It is assumed that only $25 \%$ of the workers in the Target Bay remain until the warnings. This assumption is based on the realization of the clear and present danger of being in the Target Bay during a shot and the motivation to minimize worker maintenance exposures to radiation. These would be extra incentives for workers to finish their jobs quickly and leave the Target Bay in a more timely manner than in the other locations.

The second branch in the event tree occurs at the top event "Access Control fails to track entry". A simple fault tree was used to model this failure (see Figure 8). The fault tree consists of an "OR" gate combining the events "Single access not recorded" and "Multiple access bypasses system". A generic failure rate for a recorder is used to represent the single access failure (see Table 1). Since multiple person access (i.e., "tailgating") is controlled administratively, a failure of administrative control was applied here. This fault tree applies to the Target Bay and Laser Bays. Personnel entry into the Capacitor Bays is not tracked by the Access Control System, but rather depends on a physical key system, which is administratively controlled. Therefore, failure to track an entry into a Capacitor Bay is modeled by the failure of an administrative control. This approach was used in the Capacitor Bays since a limited number of entries is expected compared to the laser bays and the target bay.

The third top event on the event trees is a "Person fails to leave". This event is further developed in a fault tree (see Figure 9). The structure of the fault tree is the same for each location. The fault tree considers a failure to egress as an "OR Gate" including the events "Egress not attempted" with "Egress prevented". The event "Egress not attempted" occurs when either the warnings are ignored or the warnings fail. The other side of the tree, "Egress prevented" is modeled by an "OR Gate" including the events "Doors fail to open" with "Worker Incapacitated".

Although estimates for "Worker Incapacitated" are rather crude, the "Person fails to leave" fault tree is dominated by the human error "Warnings Ignored". Experience has shown that despite the presence of fatal hazards, humans ignore warnings at the probability values listed in Table 1.

The fourth top event in the event tree is "Sweep fails to remove person". This is modeled as a single human error of "Failure of Visual Inspection". Several probabilities are applied to this event, depending on location and access control system status. For laser bay locations, the sweep has a higher probability of failure than other locations due to the large and complex volume to be swept there. If the access control system fails to track an individual, then a subsequent 
Figure 8: Fault Tree for Top Event \#2 9E-4

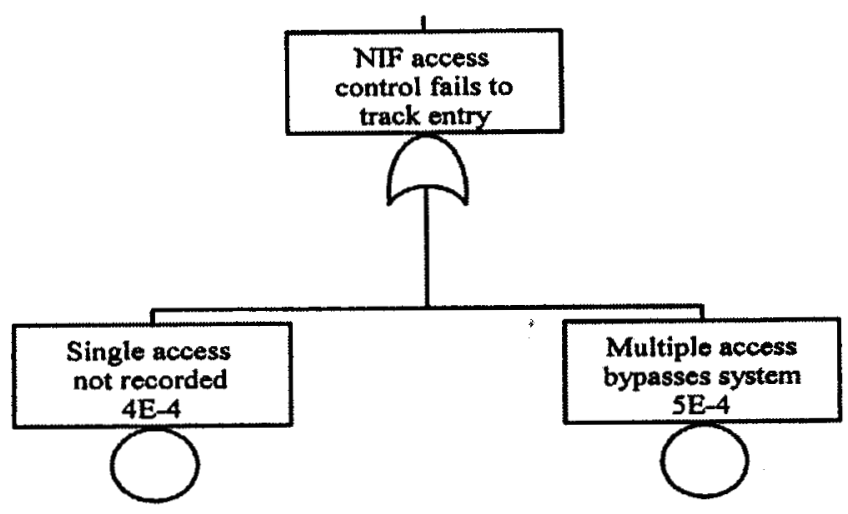




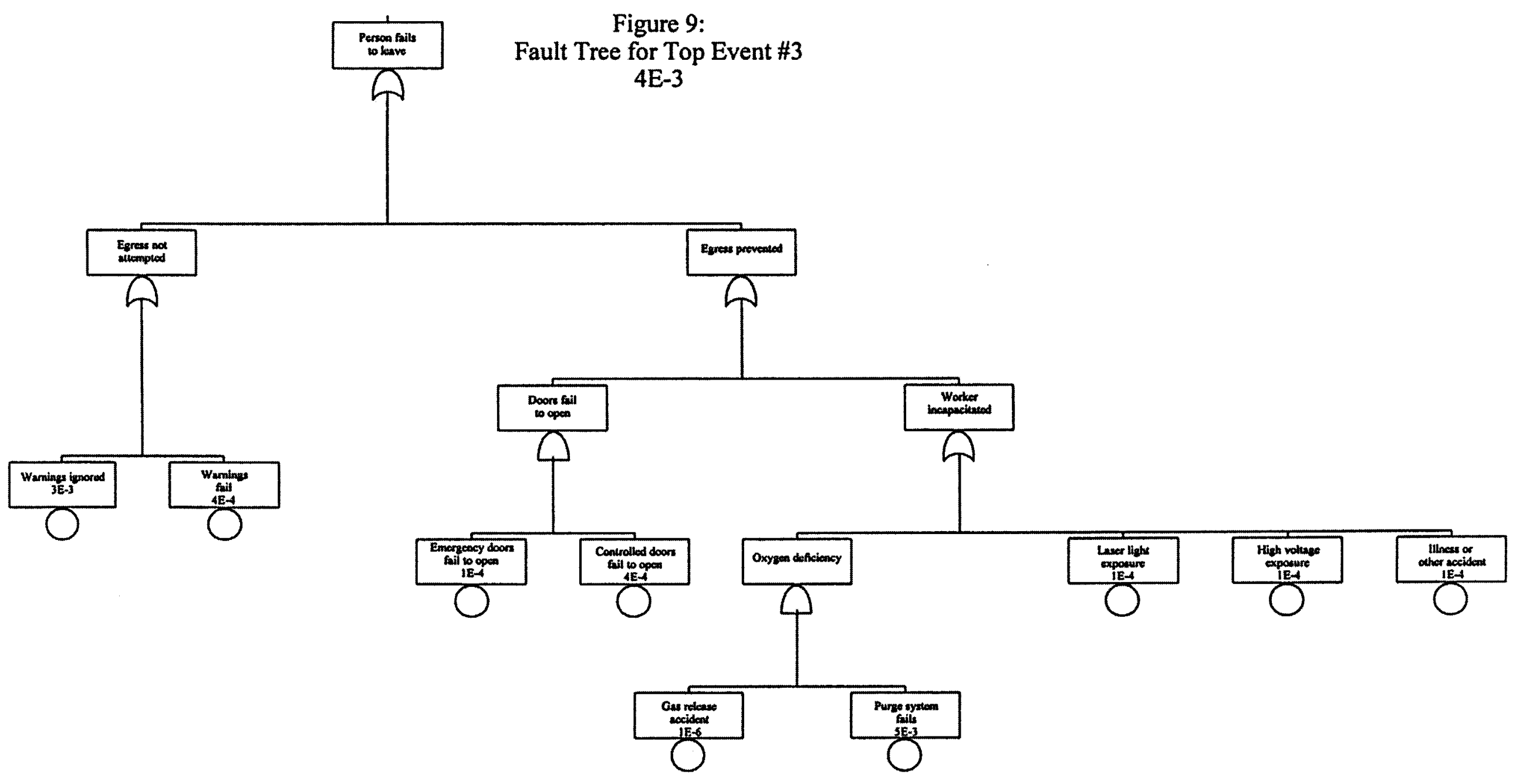


sweep has no specific target and is more likely to fail. On the other hand, if the access control system does track the individual, then the person performing the sweep knows where to look and who to find.

The fifth top event is "Shot sequence started". This event applies when the Access Control System indicates a person is present in a laser bay or target bay, or when an access is tracked by administrative control inside a capacitor bay. In these situations, it is expected that procedures would require that all personnel be accounted for before the permissives are issued to begin the shot sequence. The human interface between the Access Control System and the Safety Interlock System could fail and begin the shot sequence regardless of the indication of personnel occupying a hazardous area. This is modeled as a failure of administrative control.

The sixth and final top event in the event trees is "Person exposed to fatal hazard". This is location-specific, and is modeled as a fault tree for the laser bays and capacitor bays (see Figures 10 and 11). For the target bay, the probability is the ratio of high yield shots to total shots (\# shots $>1 \mathrm{MJ}=50 / 746=0.07$ ), since anyone in the target bay is likely to be killed by prompt radiation from a high yield shot (> $1 \mathrm{MJ}$ ). For a fatal hazard in a laser bay, the fault tree is simply an "AND Gate" combining an electrical system failure and the probability the person in the laser bay is close enough to the hazard to be killed. For a fatal hazard in a capacitor bay, the fault tree is an "OR Gate" combining shrapnel hazard from an exploding capacitor failure and an electrical system failure. Each of these is combined through an "AND Gate" with the probability the person in the capacitor bay is close enough to the hazard to be killed.

Once all the top events are quantified for an event tree, the individual sequences for each event tree can be quantified. The result of each sequence is listed as either "OK" meaning the person got out safely, or "Fatality". The fatality sequences can be summed to find the total fatality frequency estimate for that location per shot. Multiplying by the planned number of shots per year (746) gives an estimate for the fatality frequency for that location on an annual basis. These results are summarized in Table 2 . The analysis shows that it is credible $\left(>10^{-6} / \mathrm{yr}\right.$ ), though unlikely, that a worker could be killed at $\mathrm{NIF}^{2}$. Clearly, the risk in the target bay dominates the total risk for NIF. This is mainly due to the presence of a fatal prompt radiation hazard in the target bay for all high yield shots. Fatal hazards are only present in the laser bays and capacitor bays if an unlikely failure occurs during a shot.

It must be emphasized that these estimates are very conservative. With a strong training program, it may be possible to reduce the probability of persons failing to leave an area when warned. Actual experience with sweeps in the target and capacitor bays may show them to be more effective than what is modeled here.

\footnotetext{
${ }^{2}$ Based on the PSAR (LLNL, 1996), and because of the low probability of occurrence, this risk is comparable to the risk for a worker performing routine tasks in radiological areas at NIF.
} 
Figure 10

Fault Tree for Top Event \#6: Laser Bays

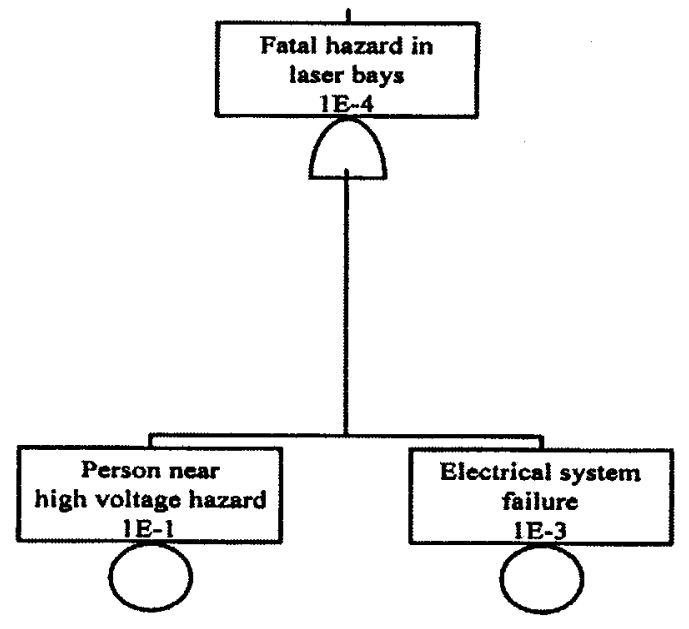


Figure 11

Fault Tree for Top Event \#6: Capacitor Bays

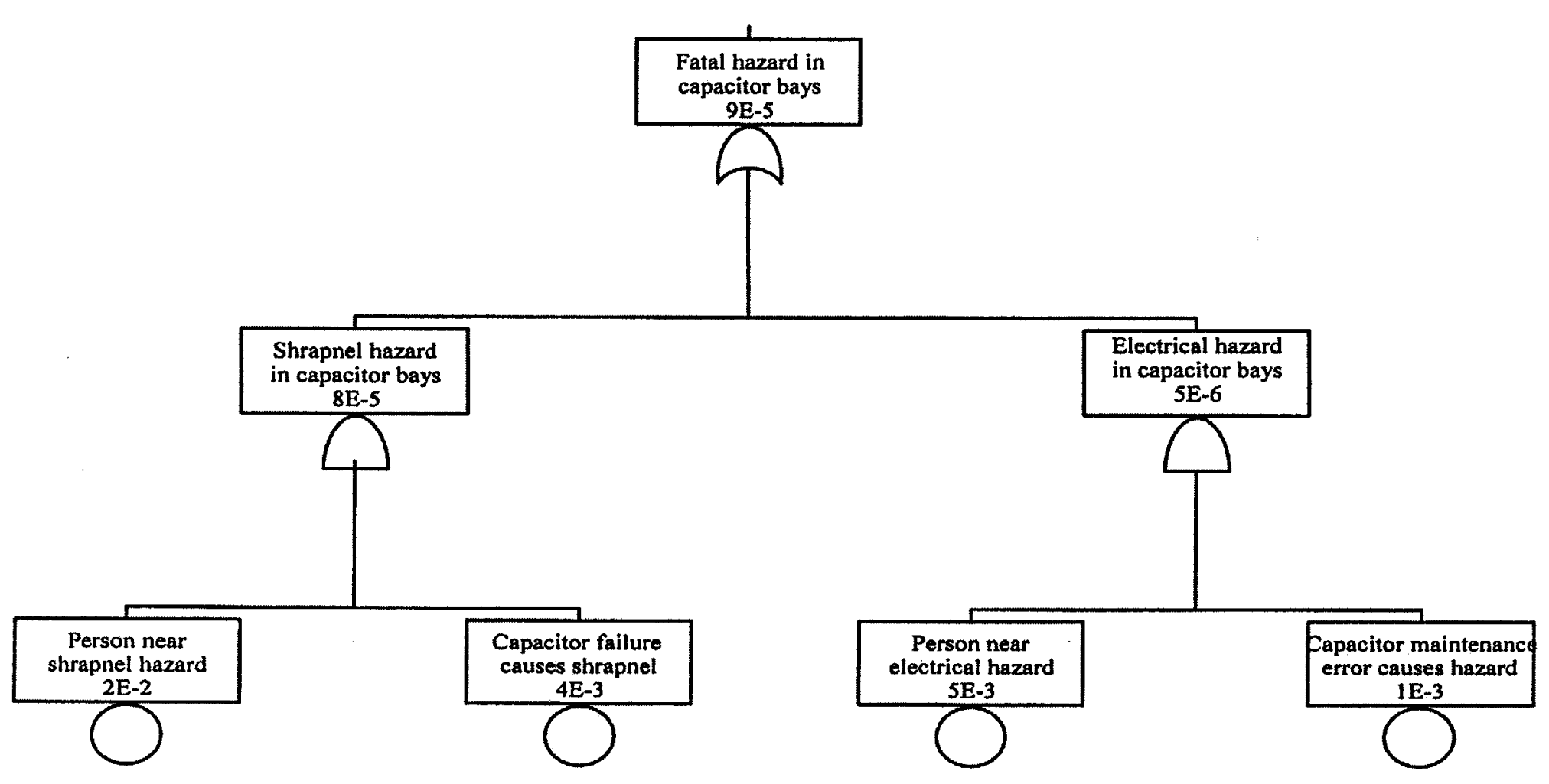


Nevertheless, these results provide some basis for the residual risk that would exist in the operation of NIF, given the assumed performance of the Access Control System. If lower residual risk is required, then one solution is to require the Access Control System to be designed with higher reliability than what is assumed here. If the residual risk is well below acceptable values, then it's possible to relax constraints on some controls. An example of this would be to not require a sweep in the laser bays, since it is time-consuming and its small contribution to safety is not cost-effective. Or, this could be a focused sweep, where effort is concentrated on assuring that no one remains in the vicinity of the potential high voltage hazard in the laser bays. 


\section{Table 1. Fatality During NIF Shot - Basic Event Data Justification and Assumptions}

\begin{tabular}{|c|c|c|}
\hline Event Description & Value & Source \\
\hline Shot sequence duration & $\begin{array}{l}365 \mathrm{~d} / \mathrm{yr}{ }^{*} \\
24 \mathrm{hr} / \mathrm{d} / \\
746 \mathrm{shots} / \mathrm{yr}= \\
11.7 \mathrm{hr} / \mathrm{shot}\end{array}$ & Assumption \\
\hline \multicolumn{3}{|c|}{ Workers Enter NIF (Initiating Event) } \\
\hline Laser Bay entries & 50 per shot & Assumption \\
\hline Capacitor Bay entries & 10 per shot & Assumption \\
\hline Target Bay entries & 50 per shot & Assumption \\
\hline \multicolumn{3}{|c|}{ Job Not Finished (Top Event \#1) } \\
\hline Job not finished & $\begin{array}{l}2.5 \times 10^{-1} \text { for } \\
\text { Target Bay, } \\
5 \times 10^{-1} \text { for other } \\
\text { locations }\end{array}$ & $\begin{array}{l}\text { Assumption on the fraction of } \\
\text { workers who enter and have not } \\
\text { completed their jobs before the } \\
\text { continuing shot sequence } \\
\text { approaches the time fatal hazards } \\
\text { are possible, and are therefore } \\
\text { susceptible to remaining behind. }\end{array}$ \\
\hline \multicolumn{3}{|c|}{ Access Control Fails to Track Entry (Top Event \#2 and Figure 8 Fault Tree) } \\
\hline $\begin{array}{l}\text { Single access not } \\
\text { recorded }\end{array}$ & $\begin{array}{l}3.0 \times 10^{-5} / \mathrm{hr}^{*} \\
11.7 \mathrm{hr}= \\
4 \times 10^{-4} \\
\text { Applicable to } \\
\text { laser bays and } \\
\text { target bay. }\end{array}$ & $\begin{array}{l}\text { WSRC-TR-93-262 (Blanton and } \\
\text { Eide, 1993) p.42, Recorder failure. }\end{array}$ \\
\hline $\begin{array}{l}\text { Multiple access bypasses } \\
\text { system }\end{array}$ & $5 \times 10^{-4}$ & $\begin{array}{l}\text { WSRC-TR-93-581 (Benhardt, } \\
\text { 1994) p. 12, Failure of } \\
\text { Administrative Control, low mean } \\
\text { value for routine, repetitive } \\
\text { circumstances. }\end{array}$ \\
\hline $\begin{array}{l}\text { Access control system } \\
\text { fails in capacitor bays }\end{array}$ & $5 \times 10^{-3}$ & $\begin{array}{l}\text { WSRC-TR-93-581 (Benhardt, } \\
\text { 1994) p.12 Failure of } \\
\text { Administrative Control, nominal } \\
\text { mean value for typical } \\
\text { circumstances. The capacitor bays } \\
\text { are not governed by an automated } \\
\text { access control system, but rather } \\
\text { depend on a manual key system } \\
\text { based on administrative control. }\end{array}$ \\
\hline
\end{tabular}




\begin{tabular}{|c|c|c|}
\hline \multicolumn{3}{|c|}{ Person Fails to Leave (Top Event \#3 and Figure 9 Fault Tree) } \\
\hline Warnings ignored & $3.0 \times 10^{-3}$ & $\begin{array}{l}\text { WSRC-TR-93-581 (Benhardt, } \\
\text { 1994) p13, Failure to Respond to } \\
\text { Compelling Signal, low mean } \\
\text { value for few competing signals } \\
\left(\mathrm{HEP}=3.0 \times 10^{-3}\right)\end{array}$ \\
\hline Warnings fail & $\begin{array}{l}3.0 \times 10^{-5} / \mathrm{hr} * \\
11.7 \mathrm{hr}= \\
4 \times 10^{-4}\end{array}$ & $\begin{array}{l}\text { WSRC-TR-93-262 (Blanton and } \\
\text { Eide, 1993) p.41, Instrumentation } \\
\text { and Control Alarm/Annunciator } \\
\text { Fails to Alarm }\end{array}$ \\
\hline $\begin{array}{l}\text { Emergency doors fail to } \\
\text { open }\end{array}$ & $1 \times 10^{-4}$ & $\begin{array}{l}\text { Conservative estimate based on } \\
\text { engineering judgment for the } \\
\text { failure of a simple piece of } \\
\text { hardware }\end{array}$ \\
\hline $\begin{array}{l}\text { Controlled doors fail to } \\
\text { open }\end{array}$ & $\begin{array}{l}3.0 \times 10^{-5} / \mathrm{hr} * \\
11.7 \mathrm{hr}= \\
4 \times 10^{-4}\end{array}$ & $\begin{array}{l}\text { WSRC-TR-93-262 (Blanton and } \\
\text { Eide, 1993) p.42, Programmable } \\
\text { Logic Controller Failure }\end{array}$ \\
\hline Gas release accident & $\begin{array}{l}1.0 \times 10^{-9} \\
/(\mathrm{hr} * \mathrm{ft}) * 100 \\
\mathrm{ft} * 11.7 \mathrm{hr}= \\
1 \times 10^{-6}\end{array}$ & $\begin{array}{l}\text { WSRC-TR-93-262 (Blanton and } \\
\text { Eide, 1993) p.31, Compressed gas } \\
\text { system piping rupture }\left(1.0 \times 10^{-9}\right. \\
\text { hr-ft), assume } 100 \mathrm{ft} \text { of vulnerable } \\
\text { piping in the occupied area }\end{array}$ \\
\hline $\begin{array}{l}\text { HVAC purge system } \\
\text { fails }\end{array}$ & $\begin{array}{l}5.0 \times 10^{-3} \text { per } \\
\text { demand }\end{array}$ & $\begin{array}{l}\text { WSRC-TR-93-262 (Blanton and } \\
\text { Eide, 1993) p.34, failure of a } \\
\text { fan/blower to start }\end{array}$ \\
\hline Laser light exposure & $1 \times 10^{-4}$ & $\begin{array}{l}\text { Conservative estimate based on } \\
\text { engineering judgment }\end{array}$ \\
\hline High voltage exposure & $1 \times 10^{-4}$ & $\begin{array}{l}\text { Conservative estimate based on } \\
\text { engineering judgment }\end{array}$ \\
\hline Other accident or illness & $1 \times 10^{-4}$ & $\begin{array}{l}\text { Conservative estimate based on } \\
\text { engineering judgment }\end{array}$ \\
\hline
\end{tabular}




\begin{tabular}{|c|c|c|}
\hline \multicolumn{3}{|c|}{ Sweep Fails to Remove Person (Top Event \#4) } \\
\hline Sweep fails & $\begin{array}{l}1 \times 10^{-1} \\
5 \times 10^{-1} \\
1 \times 10^{-2}\end{array}$ & $\begin{array}{l}\text { WSRC-TR-93-581 (Benhardt, } \\
\text { 1994) p.53, Failure of Visual } \\
\text { Inspection, nominal mean value } \\
\text { when the procedure is usually } \\
\text { followed and the event is easy to } \\
\text { observe. Applies to target bay and } \\
\text { capacitor bays for routine sweeps, } \\
\text { laser bays for specific sweeps. } \\
\text { High mean value applies to laser } \\
\text { bays for routine sweeps, due to } \\
\text { "event difficult to observe". } \\
\text { Low mean value applies to target } \\
\text { bay and capacitor bays when the } \\
\text { sweep is looking for a specific } \\
\text { person believed to be there. }\end{array}$ \\
\hline \multicolumn{3}{|c|}{ Human Error - Shot Sequence Started $\quad$ (Top Event \#5) } \\
\hline $\begin{array}{l}\text { Human error - shot } \\
\text { sequence started }\end{array}$ & $5 \times 10^{-4}$ & $\begin{array}{l}\text { WSRC-TR-93-581 (Benhardt, } \\
\text { 1994) Failure of Administrative } \\
\text { Control, low mean value for } \\
\text { routine, repetitive circumstances }\end{array}$ \\
\hline \multicolumn{3}{|c|}{$\begin{array}{c}\text { Person Exposed to Fatal Hazard in Laser Bays } \\
\text { (Top Event \#6 and Figure 10 Fault Tree) }\end{array}$} \\
\hline $\begin{array}{l}\text { Person near high voltage } \\
\text { hazard }\end{array}$ & $1 \times 10^{-1}$ & $\begin{array}{l}\text { Conservative estimate based on } \\
\text { engineering judgment that a person } \\
\text { in the laser bay has only a } 10 \% \\
\text { chance of being electrocuted when } \\
\text { a flashlamp fails. }\end{array}$ \\
\hline Electrical system failure & $1 \times 10^{-3}$ & $\begin{array}{l}\text { Based on test data showing } 1 \text { flash } \\
\text { lamp failure in } 6.6 \times 10^{6} \text { shots, times } \\
7680 \text { flashlamps (Dreifuerst, } \\
2000 \text { ). Assumes that a fatal } \\
\text { electrical hazard will only be } \\
\text { caused by a flashlamp failure. }\end{array}$ \\
\hline \multicolumn{3}{|c|}{ Person Exposed to Fatal Hazard in Target Bay (Top Event \#6 in Figure 5) } \\
\hline $\begin{array}{l}\text { Person near prompt } \\
\text { radiation hazard }\end{array}$ & $7 \times 10^{-2}$ & $\begin{array}{l}\text { Based on the assumed ratio of high } \\
\text { yield shots to total shots (\# shots }> \\
1 \mathrm{MJ}=50 / 746=0.07 \text { ) }\end{array}$ \\
\hline
\end{tabular}




\begin{tabular}{|l|l|l|}
\hline \multicolumn{2}{|c|}{$\begin{array}{l}\text { Person Exposed to Fatal Hazard in Capacitor Bays } \\
\text { Top Event \#6 and Figure 11 Fault Tree) }\end{array}$} \\
\hline $\begin{array}{l}\text { Person near electrical } \\
\text { hazard }\end{array}$ & $5 \times 10^{-3}$ & $\begin{array}{l}\text { Assumption that only a single } \\
\text { module is failed and that a person } \\
\text { in a capacitor bay is contacting one } \\
\text { of the 192 modules. }\end{array}$ \\
\hline $\begin{array}{l}\text { Capacitor maintenance } \\
\text { error causes electrical } \\
\text { hazard }\end{array}$ & $1 \times 10^{-3}$ & $\begin{array}{l}\text { WSRC-TR-93-581 (Benhardt, } \\
\text { 1994) Failure to Restore Following } \\
\text { Maintenance, nominal mean value } \\
5 \times 10^{-3}, \text { times the conditional } \\
\text { probability of a module } \\
\text { maintenance per shot (1 } \\
\text { maintenance per 1000 module } \\
\text { shots * 192 modules = .2) }\end{array}$ \\
\hline $\begin{array}{l}\text { Person near shrapnel } \\
\text { hazard }\end{array}$ & $2 \times 10^{-2}$ & $\begin{array}{l}\text { Assumption that a person is } \\
\text { subjected to a fatal shrapnel hazard } \\
\text { from the nearest 4 capacitor } \\
\text { modules out of the total of 192. }\end{array}$ \\
\hline $\begin{array}{l}\text { Capacitor module failure } \\
\text { causes shrapnel }\end{array}$ & $\begin{array}{l}\mathrm{P}=3 / 746= \\
4 \times 10^{-3}\end{array}$ & $\begin{array}{l}\text { Based on extrapolations from test } \\
\text { data, assume 3 catastrophic } \\
\text { failures per year (per Mark } \\
\text { Newton), divided by the assumed } \\
\text { number of shots per year. }\end{array}$ \\
\hline
\end{tabular}




\section{Table 2. Summary of Event Tree Data and Results}

\begin{tabular}{|l|l|l|l|}
\hline & Target Bay & Laser Bays & Capacitor Bays \\
\hline $\begin{array}{l}\text { Number of entries } \\
\text { per shot sequence }\end{array}$ & 50 & 50 & 10 \\
\hline Job not finished & .25 & .5 & .5 \\
\hline $\begin{array}{l}\text { Access control fails } \\
\text { to track entry }\end{array}$ & $9 \times 10^{-4}$ & $9 \times 10^{-4}$ & $5 \times 10^{-3}$ \\
\hline Person fails to leave & $4 \times 10^{-3}$ & $4 \times 10^{-3}$ & $4 \times 10^{-3}$ \\
\hline Generic sweep fails & $1 \times 10^{-1}$ & $5 \times 10^{-1}$ & $1 \times 10^{-1}$ \\
\hline Specific sweep fails & $1 \times 10^{-2}$ & $1 \times 10^{-1}$ & $1 \times 10^{-2}$ \\
\hline $\begin{array}{l}\text { Human error - shot } \\
\text { sequence started }\end{array}$ & $5 \times 10^{-4}$ & $5 \times 10^{-4}$ & $5 \times 10^{-4}$ \\
\hline $\begin{array}{l}\text { Person exposed to } \\
\text { fatal hazard }\end{array}$ & $7 \times 10^{-2}$ & $1 \times 10^{-4}$ & $9 \times 10^{-5}$ \\
\hline $\begin{array}{l}\text { Sum of fatal } \\
\text { sequences per shot }\end{array}$ & $3 \times 10^{-7}$ & $5 \times 10^{-9}$ & $9 \times 10^{-10}$ \\
\hline $\begin{array}{l}\text { Fatalities per year } \\
\text { for 746 shots }\end{array}$ & $2 \times 10^{-4}$ & $4 \times 10^{-6}$ & $7 \times 10^{-7}$ \\
\hline
\end{tabular}

\section{CONCLUSIONS AND RECOMMENDATIONS}

This report provides an analysis of the baseline Access Control System for the National Ignition Facility and assesses its effectiveness at controlling access to hazardous locations during full NIF operations. The various hazards present during a NIF shot sequence have been reviewed, and the effectiveness of a proposed system of controls at preventing access while the hazards are present has been examined.

Event trees with supporting fault trees were used to model the scenarios that could result in a fatality during a NIF shot sequence. The scenarios were based on an individual being in a hazardous NIF location, then being exposed to a fatal hazard during a shot sequence. A preliminary quantification was done from which the performance criteria for the Access Control System can be assessed and from which the required effectiveness of other controls can be determined.

The Event Tree - Fault Tree analysis shows that a fatality in the Capacitor Bays during a specific NIF shot sequence is not a credible event. The Access Control System, functioning with the assumed failure rate (see Table 1) performs sufficiently well. However, when considered on a yearly basis, a fatality in the Target Bay is clearly credible, and a fatality in the Laser Bays is marginally credible considering the large uncertainty and conservatism built into the analysis. High efficiency sweeps make a positive contribution to safety and 
should be required in the Target Bay and Capacitor Bays. In the Laser Bays, sweeps are less reliable, difficult to execute, and have a smaller potential contribution to safety. In the Laser Bays, the sweeps need not be exhaustive because of the institution of the other controls. Focused sweeps, where effort is concentrated on assuring that no one remains in the vicinity of the potential high voltage hazard in the laser bays, may be more effective. This could be facilitated by establishing control zones, such as the high voltage cable area above amplifiers in laser bays. These would require key control access, utilizing a key tree that is interlocked to the Safety System. These areas would be locked from access unless a key is removed from tree that signals the safety system that the area has been opened. All entrants must take a key from tree. The last person to leave is responsible for sweeping the area and locking access.

Two other improvements should also be considered. The first is to install an automatic system to prevent multiple accesses on a single badge read, an "antitailgating" system. The second is to install an automatic link between the Access Control System and the Safety Interlock System that would lock out the permissives for a shot sequence whenever personnel are indicated to occupy the hazardous areas. The two automatic fixes would increase the overall reliability of access control by replacing the potential for two of the human errors identified in this study with more reliable automatic systems.

When taken on an annual basis (up to 746 shots/yr), and with the assumed failure rate for the Access Control System, a fatality in the Target Bay is credible $\left(>10^{-6} / \mathrm{yr}\right.$ ). The NIF PSAR (LLNL, 1996) and draft FSAR (LLNL, 1999) indicate that this risk is comparable to that experienced by a NIF worker performing routine maintenance activities in radiological areas (dose incurred $\leq 500$ mrem/yr). Additional analysis is warranted to better understand that risk and possibly develop new or improved controls to lower the risk, such as a more reliable tracking system for the target bay. Additional analysis might include a detailed reliability model of the software and hardware for both the Access Control System, and the Safety Interlock System as they function for the Target Bay. The greatest uncertainty lies in the human errors modeled. More detailed human reliability modeling could also be included in fault trees for the "Failure to Egress" and "Sweep Failure". In general, more detailed analysis may make it possible to relax some of the conservative assumptions used here, giving confidence that the residual risk is actually lower than this conservative estimate.

\section{Acknowledgements}

The authors would like to acknowledge the contributions of the members of the Facility Access Working Group, specifically, Greg Tietbohl, Brian Mac Gowan, Allyn Saroyan, Bob Reed, Gary Dreifuerst, Mike Trent, Nicolas Pierre, and Chin Ma for their input. 


\section{References}

C. H. Blanton and S. A. Eide (1993), Savannah River Site Generic Data Base Development, WSRC-TR-93-262, June 30, 1993.

H. C. Benhardt, et. al. (1994), Savannah River Site Human Error Data Base Development for Nonreactor Nuclear Facilities, WSRC-TR-93-581, February 28, 1994.

S.J. Brereton et al., (2001), "Analysis and Control of Hazards Associated with NIF Capacitor Module Events", MESN99-066-OA, March 2001.

G. Dreifuerst (2000), private communication, December 2000.

LLNL (1996), "National Ignition Facility Preliminary Safety Analysis Report", UCRL-ID-123759, Lawrence Livermore National Laboratory, September 1996.

LLNL (1999), "National Ignition Facility Final Safety Analysis Report", Preliminary Draft, UCRL-ID-139329, March, 1999. 


\section{Appendix A: Access Control Technologies}

\section{A.1 CaRd Reader TEChNology}

Most companies offer two different kinds of technologies, the proximity cards and readers and the Wiegand cards and readers.

The proximity technology recognizes cards at a short distance from the reader. Wiegand technology requires cards to be inserted into the reader.

Both kinds of cards and readers are available, and they come in different varieties:

- Simple cards for the proximity technology

- Simple cards for the Wiegand technology

- For both, cards with photo ID

- Combination cards offering proximity and Wiegand technologies

These systems are often combined with locking device, such as:

- Magnetic locks

- Electric locks

- Turnstile systems

- Barrier systems.

One issue is to control ingress and egress of materials. In fact, the NIF includes several large doors and such systems (proximity and Wiegand technologies) may be restrictive for accomplishing work.

Others systems are available, such as the Automatic Personnel Identification or the Automatic Vehicle Identification system:

\section{- Automatic Personnel Identification}

The Automatic Personnel Identification System (APID) provides hands-free access control and advanced personnel monitoring.

Features:

- Hands-free access control.

- Personnel tracking.

- Multi-tag read (simultaneously identifies multiple tags).

The APID system operates totally hands free. The small personnel tags communicate with readers through an antenna located next to the doorway or concealed inside a ceiling or wall. There are no cards or buttons to press or codes to remember. 
The personnel tag can be used to gain access to areas such as building entrances and elevators. By carrying a tag in a pocket, access can also be monitored at a vehicular-gated entry.

\section{- Automatic Vehicle Identification}

The Automatic Vehicle Identification System (AVID) provides the most flexible, long-range vehicle identification system on the market. Whether you need simple gate access or advanced vehicle tracking and fleet management capabilities, the AVID system provides a solution for both your current and future needs.

Features:

- Automatic hands free operation.

- Flexible coverage zone supports single or multi-lane applications.

- Multi-tag read identifies multiple tagged vehicles across heavy traffic areas.

The AVID system provides a fast, cost-effective means of securing perimeter gates. Unobtrusive vehicle mounted tags uniquely identify each vehicle, allowing the gate control system to quickly authorize or prevent entry to, or exit from, secure areas. The system instantaneously identifies approaching vehicles, allowing the control system to quickly process and clear authorized vehicles while logging a record of entry or exit.

\section{- Internet Addresses}

\section{http://www.hidcorp.com}

HID Corporation has become the industry leader in providing access control cards and readers to the security industry. HID has led the access control market with product innovations such as asset tracking using RFID technology, field programmable cards, and a broad product range that meets virtually all access control requirements. HID has embedded proximity technology in logical access/computer log-on readers, electronic locks, alarm keypads, biometrics equipment, dye-sublimation card printers, parking equipment and smart cards.

As the world's largest proximity and Wiegand card and reader manufacturer, HID is committed to providing the most technologically advanced products combined with excellent customer and technical service. Since 1995, HID has shipped over 100 million cards, tags and other credentials to locations on every continent.

http://www.doorking.com

APID and AVID system.

http://www.identicard.com 


\section{A.2. BIOMETRICS TECHNOLOGIES}

Biometric identification is the process of proving ones identity via a physical measurement. There are several possibilities, such as:

- Hand geometry,

- Facial recognition,

- Iris scanning,

- Retinal scanning,

- Signature verification,

- Voice analysis,

- Fingerprint,

- Vein pattern.

\section{DISAVANTAGES}

- Hand geometry devices are subject to physical changes, which makes them less than ideal for large database sizes, where identification versus verification is required. These devices are also typically large and, therefore, difficult to integrate into many applications.

- Facial recognition technology can be fooled by photographs and thermal facial recognition is typically cost prohibitive, thereby limiting its application in mass-market applications.

- Iris scanning has remained costly, is subject to user motion, and requires large data storage.

- Retinal scanning has also remained expensive and is subject to user health concerns over infrared or laser scanning of the retina.

- Signature verification is subject to user physical changes over time and is susceptible to forgery.

- Voice analysis is subject to user physical changes and can be forged through the use of devices capable of recording and altering individual voices.

- Fingerprints are widely accepted as an infallible method of identification. Viewed as the most reliable and affordable technology for many identification applications.

- Vein pattern recognition technology utilizes vein patterns in the back of the hand, which is a unique trait for every individual.

\section{AdVANTAges}

- Hand geometry - Easy to use.

- Iris scan - Can be used for one-to-many identification applications. 
- Facial recognition a cost effective and reliable verification technology when combined with fingerprints.

- Retinal recognition can be used for one-to-many identification applications.

- Signature dynamics widely applied as a convenient methodology for verification.

- Voice analysis well suited for remote or local verification applications. Low cost and non-intrusive.

NOTE: The iris scan is the most mathematically unique feature of the human body; more unique than fingerprints. Identification accuracy of iris recognition even outperforms DNA.

\section{- INTERNET ADDRESSES}

http://www.biometrics.org

The Biometric Consortium serves as the US Government's focal point for research, development, test, evaluation, and application of biometric-based personal identification/verification technology. This site provides a lot of other addresses.

OTHERS :

http://www.biometricid.com

http://www.biometrics2000.com

http://www.controlmod.com

http://www.biomet.ch

http://www.identix.com

http://www.recogsys.com

\section{A.3 Nonintrusion SYSTEM}

Another issue concerning the NIF facility is the fact personnel can enter in the target bay after a shot during the cooldown period for radiation decay.

In order to forbid the entrance of personnel in hazardous zones, two different kind of materials are available, other than programming door openings:

- the infrared barriers

- the hyperfrequency barriers.

The infrared barriers consist of several infrared beams produced by cells. An intrusion alarm is initiated when beams are broken.

The limits of this system are:

- A distance between the transmitter and the receiver of less than $100 \mathrm{~m}$

- A height of $1.90 \mathrm{~m}$. 
The hyperfrequency barriers consist of a transmission of a wave of $9900 \mathrm{MHz}$ between a transmitter and a receiver. If someone crosses the zone, it initiates the intrusion alarm

The limits of this system are:

- A distance between the transmitter and the receiver of less than $200 \mathrm{~m}$

- Internet Addresses

http://www.sorhea.fr

\section{A.4. Detected occupancy}

In order to detect unoccupancy several systems can be used :

- a sweep of the facility,

- a video surveillance system,

- a key-lock system

- a infrared scan,

- a tracking personnel system.

The sweep and the video surveillance system are not the highest reliability systems.

The key-lock system seems to be a simple but efficient system. It has already been used in others facility like NOVA.

An infrared scan is a possible solution. It would consist in a system of infrared cameras and a computer system used to detect people in the facility, based on their thermal signature. One disadvantage of this kind of system is the number of cameras required to give complete coverage of the area.

- Internet Addresses

- INFRARED DETECTION

http://www.infrred.com

http://www.dscuk.co.uk/detection devices.htm

http://www.x20.org

- TRACKING PERSONNEL

http://www.sovtechcorp.com 


\section{A.5. Tallgate Detection Systems}

A Tailgate Detection System is used in conjunction with access control devices to insure only one pedestrian enters a secured passageway for each authorized entry. This authorized entry may be via a valid card read, valid PIN code, remote door release, etc.

These type systems consist of a sensing array and a signal processor. Infrared sensors in the array establish two narrow walls of detection to determine the direction and number of pedestrians passing an access control point. The source and detector arrays are typically mounted as part of the door trim. The processor combines the signals to detect and report violations both locally, through an integral sounder, and remotely through an alarm contact.

The system senses and processes direction and pedestrian count information on a cycle basis. The cycle is initiated when a valid card is used. During the cycle, any number of pedestrians my pass the detector without alarm as long as each passage is preceded by an access granted signal from the access/door control system. Each subsequent access granted signal resets the processor to allow one more pedestrian past the sensing array.

In the event of an unauthorized entry or tailgating, the system latches into alarm. Once in alarm, the system may be reset using a key switch, or with a remote contact. The system may be bypassed locally using a key switch or with a remote contact. 


\section{Appendix B: Survey of Access Control Systems at Other Facilities}

At the SLAC and FERMI accelerators, which are quite sizeable, there are many different interlock and sweep or "search" procedures, all area dependent. It is necessary to search an area prior to operation of the facility unless the access has been controlled in some way. Since it is usually cumbersome to maintain a controlled access situation for long periods of time, especially if there are frequent entries and egresses with large tools and equipment, a search is definitely necessary after a permitted access situation. To go to "permitted access" is a trade off between the effort to maintain "controlled access" (based on number of entries and length of access) and the complexity of the search for that particular region.

At SLAC, after "long" periods of permitted access (several hours), operators perform thorough interlock checks, and also fill out Safety Inspection Checklists. The Interlock Checks are basically an exercise of every door microswitch and emergency off button in the region. At SLAC, interlock failures are discovered once annually or less for the entire complex. Typically, a damaged emergency off button or a micro switch that has been painted over, etc. The checklists have been done for quite some time at SLAC, although now it is more formal. 
Susan Allen

Updated: June 25, $2001 \mathrm{pm}$

The table below provides a view of the current status of Project Control Procedures as of June 25, 2001.

The are 46 Project Control Procedures now in effect for the Project

38 of the Procedures have been revised and converted to the new template since July, 2000 (Lehman Review)

The goal is to bring all of the Project Control Procedures current and issued on the new procedure template by the next Project Review in Sept. 2001.

As you can see there is a quite a bit of work to be done. I need to start a very concentrated effort in July to nudge the process owners along again. Activities stop if Cindy Cassady or I are not actively making requests.

I am sure the list will grow a bit more before September.

Currently in revision and review process

\begin{tabular}{|l|l|l|l|}
\hline Procedure \# & Procedure Title & Status & Target Release date \\
\hline 5.5 & NIF Project Site Access & $\begin{array}{l}\text { Draft } \\
\text { Complete } \\
\text { for } \\
\text { review }\end{array}$ & New July 15 \\
\hline 5.11 & NIF Site Incident Analysis & In Draft & July 15 \\
\hline 7.7 & NIF Project Vendor QA Survey & $\begin{array}{l}\text { Draft in } \\
\text { progress }\end{array}$ & New July 15 \\
\hline 8.2 & Standard Content for Specs & $\begin{array}{l}\text { Suzanne } \\
\text { Cabral } \\
\text { updating }\end{array}$ & Aug 1 \\
\hline New & Lock out and Tag Out & $\begin{array}{l}\text { Working } \\
\text { Draft }\end{array}$ & July 15 \\
\hline & & & \\
\hline & & & \\
\hline
\end{tabular}

Process Owners contacted some initial work started for revision

\begin{tabular}{|l|l|l|l|}
\hline 1.2 & Cost Estimating & $\begin{array}{l}\text { Discussion } \\
\text { in mtg with } \\
\text { proj office }\end{array}$ & $\begin{array}{l}\text { Need to update to new } \\
\text { org structure and } \\
\text { reporting process } \\
\text { Sept 1, 2001 }\end{array}$ \\
\hline 1.3 & $\begin{array}{l}\text { Schedule, Preparation, Statusing } \\
\text { and Revision }\end{array}$ & $\begin{array}{l}\text { Discussion } \\
\text { in mtg with } \\
\text { proj office }\end{array}$ & $\begin{array}{l}\text { Need to update to new } \\
\text { org structure and } \\
\text { reporting process }\end{array}$ \\
\hline
\end{tabular}




\begin{tabular}{|c|c|c|c|}
\hline & & & Sept 1,2001 \\
\hline 1.6 & $\begin{array}{l}\text { Assignment of Quality } \\
\text { Assurance Levels } \\
\end{array}$ & $\begin{array}{l}\text { Discussion } \\
\text { started }\end{array}$ & Sept 1 \\
\hline 1.7 & Baseline Change Control & $\begin{array}{l}\text { Discussion } \\
\text { in mtg with } \\
\text { proj office }\end{array}$ & $\begin{array}{l}\text { Need to update to new } \\
\text { org structure and } \\
\text { reporting process } \\
\text { Sept } 1,2001\end{array}$ \\
\hline 1.8 & Action Item Tracking & & Aug 1 \\
\hline 1.9 & $\begin{array}{l}\text { Generation of Control (Cost) } \\
\text { Account Plans }\end{array}$ & $\begin{array}{l}\text { Discussion } \\
\text { in mtg with } \\
\text { proj office }\end{array}$ & $\begin{array}{l}\text { Need to update to new } \\
\text { org structure and } \\
\text { reporting process } \\
\text { Sept } 1,2001\end{array}$ \\
\hline 1.13 & NIF Project Status Reporting & $\begin{array}{l}\text { Discussion } \\
\text { in mtg with } \\
\text { proj office }\end{array}$ & $\begin{array}{l}\text { Need to update to new } \\
\text { org structure and } \\
\text { reporting process } \\
\text { Sept } 1,2001\end{array}$ \\
\hline 3.2 & Nonconformance Reporting & & Aug 1 \\
\hline 4.1 & Document and Records Control & $\begin{array}{l}\text { Brief } \\
\text { update and } \\
\text { release } \\
\text { needs new } \\
\text { revision }\end{array}$ & Sept 1 \\
\hline 4.2 & $\begin{array}{l}\text { Control of Project } \\
\text { Correspondence }\end{array}$ & $\begin{array}{l}\text { Brief } \\
\text { update and } \\
\text { release } \\
\text { needs new } \\
\text { revision }\end{array}$ & Sept 1 \\
\hline 5.15 & Risk Management & $\begin{array}{l}\text { Discussions } \\
\text { started }\end{array}$ & Sept 1 \\
\hline 6.1 & $\begin{array}{l}\text { Preparation and Revision of } \\
\text { System Design requirements }\end{array}$ & $\begin{array}{l}\text { Spoke with } \\
\text { Mark } \\
\text { Jackson, } \\
\text { Ric Beeler, } \\
\text { and Tom } \\
\text { Huppler on } \\
\text { separate } \\
\text { occasions } \\
\text { They are } \\
\text { starting } \\
\text { work }\end{array}$ & Aug 1 \\
\hline 6.2 & $\begin{array}{l}\text { Preparation and Revision of } \\
\text { Interface Control Documents }\end{array}$ & $\begin{array}{l}\text { Same as } \\
6.1 \\
\end{array}$ & \\
\hline 6.3 & $\begin{array}{l}\text { Engineering Drawing Standards } \\
\text { and Controls }\end{array}$ & $\begin{array}{l}\text { In signature } \\
\text { process } \\
\text { since April }\end{array}$ & \\
\hline 6.4 & Engineering Change Control & Discussion & Need to update to new \\
\hline
\end{tabular}




\begin{tabular}{|l|l|l|l|}
\hline & & $\begin{array}{l}\text { in mtg with } \\
\text { proj office }\end{array}$ & $\begin{array}{l}\text { org structure and } \\
\text { reporting process } \\
\text { Sept 1, 2001 }\end{array}$ \\
\hline 6.5 & $\begin{array}{l}\text { Preparation of Primary } \\
\text { Criteria/Functional } \\
\text { requirements }\end{array}$ & $\begin{array}{l}\text { Same as } \\
6.1\end{array}$ & \\
\hline 7.6 & Statement of Work & & Sept 1 \\
\hline 8.1 & $\begin{array}{l}\text { Suspect/Counterfeit Items } \\
\text { Detection and Prevention }\end{array}$ & & Aug 1 \\
\hline & & & \\
\hline & & & \\
\hline
\end{tabular}

New Procedures

\begin{tabular}{|l|l|l|l|}
\hline & Earned Value & & Sept 1 \\
\hline & OMB Report & & Sept 1 \\
\hline & $\begin{array}{l}\text { Project Status Monthly } \\
\text { Reporting }\end{array}$ & Sept 1 \\
\hline & NIF Site Incident Notification & & A break out of 5.11 \\
\hline & & & \\
\hline
\end{tabular}

Additional Procedures identified needing revision by Sept review

\begin{tabular}{|l|l|l|l|}
\hline Procedure \# & Procedure Title & Status & Target Release date \\
\hline 1.1 & $\begin{array}{l}\text { Preparation of Project Control } \\
\text { Manual Procedure }\end{array}$ & & Sept 1 \\
\hline 5.12 & $\begin{array}{l}\text { NIF Construction Site Work } \\
\text { Authorization Procedure }\end{array}$ & & Sept 1 \\
\hline & & & \\
\hline & & & \\
\hline
\end{tabular}

Procedure actions:

- Update all new Process Owner names.

- Check to see that all procedures are on new template and identified for some update by Sept 2001

- July 1 , announcement to process owners for schedule to update procedures by Sept 1, 2001

- Write proposal for procedure simplification and improvement

- Review and release updated interactive Word forms for procedures 